Botany at McGill University: Prof. Nicholas
Polunin

THE recent appointment of Dr. Nicholas Polunin to the Macdonald professorship of botany in McGill University, Montreal, was an especially suitable one in that aretic botany has long been one of Dr. Polunin's chief interests and he has devoted special attention to the flora and ecology of north-eastern Canada. Since 1930 he has made several expeditions inside the Arctic Circle, ranging from Lapland and Spitsbergen in the east through Greenland to the territories covered by the Canadian Eastern Arctic Patrol. The Canadian Department of Mines and Resources has sponsored his work on "The Botany of the Canadian Eastern Arctic" to be published in four parts, three of which have already appeared.

Dr. Polunin went to Christ Chureh, Oxford, with an open scholarship in natural science in 1927. He graduated in the Final Honours School of Natural Science in 1932 and was awarded a Goldsmith's Senior Studentship. Later he received the degrees of D.Phil. and D.Sc. In 1933 he was awarded a Henry Research Fellowship at Yale University, of which he holds the degree of M.S. (1934). Returning to Oxford he was elected to a senior research scholarship at New College, during the tenure of which he was also research associate at Harvard (1936-37). Since 1938 he has been curator of the Fielding Herbarium, Department of Botany, Oxford, and in 1939 was elected University demon. strator. In 1946 he was elected to a research fellowship at New College. With the cessation of hostilities, fieldwork again became possible, and in 1946 Polunin was granted leave of absence from Oxford in order to allow him to accept a visiting professorship at McGill and take part in further expeditions to the north-east of Canada, which he has done during the summers of 1946 and 1947 .

\section{Brigadier D. P. J. Kelly}

Brigadier D. P. J. KeLLY has recently retired from the post of controller of the Royal Army Educational Corps. Born in London in 1887 and educated at the University of Cambridge, he was commissioned into the Connaught Rangers in 1915 and was gazetted as a captain in the Army Educational Corps in 1920. Following eleven years of service in India, he returned home in 1940 and was appointed command education officer in Scottish Command. In this post he was responsible for the introduction of the war-time scheme of education, and the friendly relations which continue to exist between the Army and the Scottish universities, the Scottish Education. Department and the voluntary bodies engaged in educational work in Scotland, owe much to his ability and personality. Selected as controllor in 1944, at a time when the educational scheme for the release period was being planned, he worked in the closest co-operation with Sir Philip Morris. More recently, he has been actively engaged under Major-General Cyril Lloyd in planning the future organisation of the Royal Army Educational Corps.

\section{Scientific Development in China}

THE members of the Chinese Association for the Advancement of Science, the Natural Science Society of China, the Chinese Astronomical Society, the Chinese Meteorological Society, the Chinese Geographical Society, the Chinese Zoological Society and the Chinese Anatomical Society, gathered at their joint annual conference in Shanghai during August 30-September 1, passed resolutions, the substance of which is printed below, on the control of atomic energy and on the development of scientific research in China.

(1) Atomic research. Chinese scientific workers feel that the probing into the mysteries of atomic energy, like scientific research work in all other fields, should have as its objective the promotion of human welfare. The energy of the atomic nucleus was successfully released at a time when the democracies were locked in a life-and-death struggle with the totalitarian States; and quite naturally it was taken advantage of in the making of weapons of war. This is unfortunate for atomic energy and also for scientific research. Now that the War has been concluded and the democracies are endeavouring to bring about world co-operation, atomic research should be freed from its close-guarded secrecy, to be directed towards the advancement of the application of other achievements in atomic research.

(2) Scientific research in China. The Chinese as a race are still facing starvation and other acute shortages in this atomic age, backwardness in the development of science being one of the causes. The significance of such development is in its power to raise proportionately the standard of living. Sufficient emphasis has not hitherto been given to the funda. mental sciences; and a mature status in scientific work will not be acquired suddenly by the importation of a few instruments for atomic studies. Foundations must be laid first by the strengthening of the physical equipment for science education and by extending adequate facilities and stable living conditions to teaching and research personnel in China. What is more important, China should adopt a definite and long-range plan for the development of scientific undertakings, with the necessary budgets to carry it out to the fullest extent. If science is to serve as an important contributing factor in the reconstruction of China, it must be made to stand on firmer ground; scientific development cannot be bought ready-made.

\section{Chinese Association for the Advancement of Science}

The Chinese Association for the Advancement of Science (formerly the Science Society of China) held its twenty-fifth annual meeting during August 30-September 1 at the Academia Sinica and National Medical College of Shanghai, Shanghai, with the Natural Science, Astronomical, Meteorological, Geographical, Zoological and Anatomical Societies of China. Mr. H. C. Zen presided over the meeting; Dr. W. H. Wong discussed secrecy in scientific research and its effects, and Dr. K. C. Chu emphasized the utilization of scientific knowledge for peace. Besides the presentation of papers in different sections, there were discourses on "Atomic Energy and Peace", "Improvement of Scientific Education in China", and other public lectures.

\section{Home and Factory Power Exhibition}

A sMall exhibition entitled "Home and Factory Power" was opened in the main hall of the Science Museum by Lord Citrine, chairman of the British Electricity Authority, on October 21. The exhibition will remain open until the end of January and is intended to show visitors that it is their personal responsibility to avoid the overloading of power stations and gas plants during the peak hours. In 